Revista Psicologia: Teoria e Prática, 20(I), 85-97. São Paulo, SP, jan.-abr. 20I8. ISSN 15I6-3687 (impresso), ISSN $1980-6906$ (on-line). http://dx.doi.org//0.5935//980-6906/psicologia.v20nIp85-97. Sistema de avaliação: às cegas por pares (double blind review). Universidade Presbiteriana Mackenzie.

\title{
Fear as biopolitical device
}

\author{
Sonia Regina Vargas Mansano' \\ State University of Londrina, PR, Brazil \\ Marcos Nalli \\ State University of Londrina, PR, Brazil
}

\begin{abstract}
Fear can be understood as a component of subjectivation that runs through human history winning different contours and being expressed in affective, employment, social and sexual relationships. This article seeks to discuss the fear as a device say about biopolitics which can be understood as a set of practices, rules and customs buildings participating in the production of modes of existence. The investigation was divided in three moments: first, fear is approached in a psychoanalytic perspective, with a focus in psychodynamics of defense mechanisms; then, are analyzes the ways in which fear meets specific social functions, being widespread in relationships that minimize and weaken the subject and collectivities; finally, it explored the links between fear and bio-power, emphasizing your dissemination strategy. At the end of the study, noted that far is shared defensive as a survival strategy that can culminate in experimentation with other possibilities of existence.
\end{abstract}

Keywords: fear; subjectivity; biopolitics; contemporary times; ways of life.

\section{O MEDO COMO DISPOSITIVO BIOPOLÍTICO}

Resumo: O medo pode ser compreendido como um componente de subjetivação que atravessa a história da humanidade ganhando diferentes contornos e sendo expresso nas relações afetivas, laborais, sexuais e sociais. O presente artigo busca problematizar o medo como um dispositivo biopolítico que pode ser compreendido como um conjunto de práticas, normas, edificações e hábitos que participam da produção dos modos de existência. A investigação foi dividida em três momentos: primeiro, o medo é abordado em uma perspectiva psicanalítica, com foco na psicodinâmica dos mecanismos de defesa; em seguida, são analisadas as maneiras como o medo cumpre funções sociais específicas, sendo difundido em relações que despotencializam e enfraquecem o sujeito e as coletividades; por fim, é explorada a articulação entre medo e biopoder, enfatizando sua disseminação estratégica. Ao final do estudo, constata-se que o medo é compartiIhado como uma estratégia de sobrevivência que pode culminar na experimentação de outras possibilidades de existência.

Palavras-chave: medo; subjetividade; biopolítica; contemporaneidade; modos de vida.

\section{EL MIEDO COMO DISPOSITIVO BIO-POLÍTICO}

Resumen: El miedo puede ser entendido como un componente de subjetivación que atraviesa de la historia humana, ganar diferentes contornos y se expresa en relaciones

1 Mailing address: Sonia Regina Vargas Mansano: Universidade Estadual de Londrina. Centro de Ciências Biológicas. Departamento de Psicologia Social e Institucional. PR 445, Km 180. CEP: 86051-990. Londrina - PR. E-mail: mansano@uel.br 


\begin{abstract}
afectivas, profesionales, sociales y sexuales. Este artículo pretende problematizar el miedo como un dispositivo bio-político que puede ser entendido como un conjunto de construcciones prácticas, normas y costumbres, participando en la producción de modos de existencia. La investigación se dividió en tres momentos: primero, el miedo es abordado desde una perspectiva psicoanalítica, centrándose en la psicodinámica de los mecanismos de defensa; luego, se analiza cómo el miedo cumple funciones sociales específicas, siendo generalizado en las relaciones que despotencializam y debilitan el sujeto y la colectividades; por último, explora los vínculos entre el miedo y el bio-poder, destacando su estrategia de difusión. Al final del estudio, se señala el miedo es compartido defensivamente como una estrategia de supervivencia que puede culminar en la experimentación de otras posibilidades de existencia.
\end{abstract}

Palabras clave: miedo; subjetividad; biopolítica; época contemporánea; formas de vida.

\title{
Introduction
}

The historian Jean Delumeau (1989, p. 59) observed with unequivocal precision that "the distant, the new and the different induce fear. But there was also fear of the closest ones, i.e., the neighbors". Definitely, the circle of references and shared experiences in life were tighter long ago (in the time examined by Delumeau, that is, Europe from the 13th to the 18th century) than it is now. Right in the 21st century, however, we still live in fear for almost the very same reasons.

We continue to fear our closest ones, our neighbors, our bosses, our colleagues from work or from academy, and even our relatives, because we do not know what they are capable of and for what reasons. Today, the exposed ones are us, and not the others, our closest strangers. A functional strategy of defense consists in deep hiding, in order to protect ourselves in an imunitarian way (Brossat, 2003; Esposito, 2008, 2009); although, we still expose ourselves impudently and rampantly in the social media, which incite and support the vain promise of protection and security. If collectively diffused and shared fear is not new, we have to admit that its nature and appearance are not monolithic, coherent and one in itself, as well as our will for selfpreservation and protection: we want to be untouchables, establishing for this purpose who are the ones that may not be touched, our social outcasts.

Recent studies (Ferraz, 2017; Beck, 2011; Stengers, 2015) demonstrate how much fear is associated with situations of the everyday life already considered inevitable, as urban violence and ecological disasters. They also associate fear to situations not necessarily materialized (Glassner, 2003) even though vastly disseminated by communication devices ringing the alarm of risks and threats for entire populations.

The present paper aims to interrogate fear as a component of subjectivation that runs through the history of humanity admitting multiple shapes. In contemporary times, specifically, it reaches a particular unmeasured configuration, empowered by the medical, technological and security-related improvements accessible to most of the population. Therefore, we elaborate the following problems: Which are the new shapes of fear? How arethey socially propagated? Which are their conditions of possibility? And, mainly, which are the social and affective functions it responds to? 
In order to examine these questions, we adopted the following itinerary: first, we will approach fear as a defense mechanism in a psychoanalytical perspective. Then, we will analyze the ways in which fear, understood as a component of subjectivation, fulfill some social functions, being propagated in relationships that undermine and weaken the individuals, as well as the collective. Following the path of our analysis, we will articulate fear and biopower, stressing how its dissemination is strategically shaped in the biopolitical context. Lastly, in the final considerations, our paper will show that, far from remaining trapped in the defensive individuality or in the devices of control, fear can be understood from a critical point of view. Thus, our paper is justified because of its analysis of fear as a multifaceted subjective component that, although very close to us as an ancient shared experience, it still holds unknown and unexpected dimensions.

\section{Fear and defense mechanisms: a psychoanalytical perspective}

From the perspective of the history of Psychology, we can find an important reference to our goals in the work of Anna Freud. In 1946, Anna Freud published a book The ego and the defense mechanisms [Das Ich und die Abwehrmechanismen]. In the first part of the book, the author presents what she called the "theory of the defense mechanisms". In this text, she articulates considerations about the condition of the ego [das Ich] both as an object of science and of the psychoanalytical technique, stressing its importance to the analyst's practice. In the context of our research, we are interested in the relation between the ego [das Ich] and the so called defense mechanisms.

With regards to the psychoanalytical practice, the interest of the author on this subject matter is guided by the understanding that such mechanisms create difficulties to the accomplishment of the scope of the analysis, since "the instances of ego consider the investment of the analyst as a dangerous threat" (Freud, 1975, p.30). This reveals the ego's defensive relation when faced with something it considers dangerous or threatening - real or fictitious, it does not matter so much - since such a threat appears to the ego as exterior.

The idea of defense, according to Anna Freud, is not new. It showed up in the researches of Sigmund Freud, at least since 1984, vaguely discussed in his work on The Neuro-Psychoses of Defense, and developed with more precision and consistence in Inhibitions, Symptoms and Anxiety (1926). However, the text of Anna Freud, by the way she pictures the psychic structure and dynamics, certainly echoes other texts by her father, especially regarding the subject of the psychology of the ego, already sketched in Beyond the Pleasure Principle (1920), in which, as we all know, Sigmund Freud presents his first systematical formulation of the metapsychology, admitting, although schematically, the existence of two guiding principles or guidelines to the human actions: the principle of lust - Eros - and the controversial principle, or death drive (Todestrieb) - Thanatos. Such considerations traverse his studies in Civilization and Its Discontents (1930), New Introductory Lectures on Psycho-Analysis (published 
three years latter), or An Outline of Psycho-Analysis, which appears in 1940, as Gay (1989) and Young-Bruehl (1922) describe.

From a psychoanalytical point of view, the ego's defense mechanisms do not drive exclusively against dangers external to subjectivity (such as the psychoanalytical assault), although they obey to a belligerent dynamical defense against threats recognized as strange. According to Anna Freud, the subject as a whole do not stand in a defensive mode, already categorized (Freud, 1975), but it is the ego [das Ich] who seeks to defend itself against the instinctual dangers - which are all the same, although the causes of its identification as dangerous may vary.

In order to guarantee the harmonic, balanced and healthy integrity and synthesis of the subject, the ego [das Ich] uses the defense mechanisms when faced to threats and dangers from instinctual drives, whose only goal is its own prompt satisfaction. In turn, the ego itself does not even "consider as dangerous the drive that is fighting against" (Freud, 1975, p.52): if there is a battle against the drive is because its pure and simple satisfaction may end up in threatening consequences for the ego.

Anyway, the defensive relation of the ego against such dangers, when taken as instinctual originated, includes risks external to the ego, although paradoxically inherent to subjectivity. In order to untie the Gordian knot of this paradox, it is necessary to admit that the external or internal origin of the threat depends of a point of view. In other words, the question is this: from which bundle of relations danger arises? If the relational perspective arises from the interaction between the ego and the Id, then the instinctual dangers are external to the ego; but if the perspective arises from a wider relational frame involving other forces (besides the ego and the Id [das Es], there is schematically at least the superego [das Über-Ich]), then it is necessary to admit that danger comes from an internal origin.

Therefore, it is not the externality of danger that denotes its threatening character, but is the possibility of dissolution and disarticulation of the psychic structure of the individual, either faced by an internal or external perspective. It is up to the ego, schematically, the function to provide some protection and defense, avoiding then "every suffering that comes from either the inside or the outside" (Freud, 1975, p.87). But, as long as the significance of the trace of externality is neglected, what we should understand is not an imprudent negligence, but a much more complex deal with danger, whose boundaries between the external and the internal, because of its porosity, are not outlined, being difficult to tell the external threat from the inner danger, since they are profoundly indistinct. Well, if we cannot tell precisely one from another is because the internal and the external are merged and inserted one into another. The danger and the threat to the subject (as a structure, as a web of opposing forces) are crucially immanent to him for whatever original motivator.

Laplanche and Pontalis recognized the importance of the studies of Sigmund Freud on the defense mechanism, showing the diverse angles in which it was analyzed. The authors also stress the relevance of the studies of Anna Freud, which sustained and 
improved the concept, discussing it in a more contextualized way, supported by clinical cases:

[...] departing from concrete examples, [Anna] dedicated herself to describe the variety, the complexity and the extension of the defense mechanisms, showing primarily how the defensive objective can use diverse activities (phantasy, intellectual activity), how the defense may focus not only on drive-related requests, but on everything able to induce the development of anxiety: emotions, situations, demands from the superego, etc. (Laplanche \& Pontalis, 1991, p. 278)

It is valuable to exemplary consider the psychoanalytical approach on the defense mechanisms, especially in the studies of Anna Freud, because it reverberates a continuous and widespread movement of defensive reactions to any kind of investment. This is applicable to any phenomenon (fact or fancy) recognized as risky or dangerous. Well, if we advance in our analysis of contemporary capitalism, we may find that this plural and multifaceted investment has been multiplied and intensified, gaining new configurations when compared to the neurosis studied by Anna and Freud. By the way, we must admit that, in a certain way, Sigmund Freud himself previewed that this was not something strict to the psyche, but somehow it was directly related to its social character: he stated, not a single time, that the First (mainly) and the Second World War empirically confirmed the evidence of his theory that, beyond the principle of lust, the principle of death coexists in the human psyche. By analogy, we can say the same about the defense mechanism presented by Anna Freud: in a more subtle way than Sigmund's death drive, Anna's defense mechanisms revealed a singular way of the operations of subjectivity in face of the surrounding reality, whose belligerent conflicts of the two world wars confirm in extremis its patency and factuality.

The contemporary capitalism, marked mainly by the historical consolidation of $n$ eoliberalism, is regulated by patterns of competition and circulation of commodities in speeds and rhythms never seen, especially in the edge of this globalized era. This moment is profoundly marked by more elaborated forms of control, subtler and, therefore, dissimulated, disguised of exercises of supposed freedom. This kind of freedom is managed by the constitution of the homo oeconomicus as the object of the neoliberal model of management and government, always in the real stratum of the civil society.

Civil society, therefore, as the element of the transactional reality in the history of the technology of government, transactional reality that seems to me completely associated with this form of governmental technology called liberalism, i.e., a technology of government whose goal is its own limitation, insofar as it is arranged by the specificity of the economical process (Foucault, 2008, p. 404).

Such an economical arrangement of the social life and of the government just emerges as the restraining of the state government. But, in order to achieve this, it ends up creating many other artifacts of control and government of the conduct both 
of the population as a whole (Foucault, 1988) and of its single individuals. Instead of providing the exercise of freedom in face of the coercion of the State, it creates a subjugated subject (Candiotto, 2010). It assumes profoundly, therefore, the feature of the police, in which security and insecurity are regulated, all in the name of transparency, i.e., of mistrust (Han, 2013). And mistrust, disguised by the clamor of transparen$c y$, is nothing less than the other face of fear (Lemke, 2014).

Fear produces, therefore, a shared and controlled way of living in which the defenses are reconfigured and distributed in the social field, either by the narcissistic closure or by an overexposed self-image that, when closely observed, also keeps defensive traces, as we may see next.

\section{The (im)propriety of the fearful subjectivity}

Proceeding with our analysis of the contemporary capitalism, it is noticeable that fear turned into a widely spread component of subjectivation in society. When presenting their concept of "components of subjectivation", Guattari and Rolnik (1996, p.135) stress that "any important problem, up to a worldwide level, is fundamentally related to the mutations of subjectivity in the diverse layers of micropolitics". Fear as a component of subjectivation contains in its local micropolitical propagation the conditions of possibility required to produce specific modes of existence, which contribute to keep the subject bounded to the universes of work, production and consumption, and also to affective and emotional relationships, for example. This component reaches whatever form of social bond that apparently provide some sensation of security to the subject, who misjudges it as comfort or pleasure. In this sense, we may acknowledge some present day transfigurations regarding what psychoanalysis identified: here, pleasure is actually not opposed to death or displeasure, but is situated in the psycho-social suppression of displeasure, discomfort, inconvenience and, therefore, of threat and danger actualized by the encounter with the other.

If in the last section we defined fear in its psychoanalytical dynamics as a defense mechanism, now we will consider it in its micro-social dimension as a subjective component vastly stimulated and shared in society, whose goal is to make feasible the maintenance and expansion of a certain social organization. In the work of Christopher Lasch (1984), we find part of this understanding when he describes what he calls "the minimal self". According to him, the multiple menaces in the relational everyday life - from epidemics through wars, economic instability, deterioration of the environment and terrorism - generate a situation in which the subject is always preparing for the worst outcome. In his words, "the preoccupation with the individual, apparently so typical of our age, appears in the form of a concern about survival" (Lasch, 1984, p.9). Thereby, "the self shuts itself in a defensive core, vigilant against any adversity. The emotional balance requires a minimal self" (Lasch, 1984, p.9). But what kind of balance are we talking about? Would not it be just another piece of this contemporary production of fear with its idealized outlines? 
From this perspective, we sustain that fear, in its actual crystalized configuration, is instrumentally configured as a subjective component necessary to keep in check the gears that make the current capitalist order omnipresent. Our daily fear... A typical fearful subjectivity is easier to reaffirm the daily adaptive, nihilistic and mass-culture practices, while each one of these components is cynically described as index of autonomy and entrepreneurship. Between the edges of hiding in intimacy or self-exposing in social media, two apparently opposed conducts, there is a multifaceted combination of possibilities, which generates complex games of social insertion copiously explored by the market.

The difficulty of taking forward a critical analysis of fear, or any other undermining subjective component, is examined by Deleuze and Parnet (1998, p.75) when they affirm: "We live in a unpleasant world, where not only the people, but also the established powers are interested in the communication of sad affections. Sadness: the sad affections are all the ones that diminish our potential for action". Ahead, they associate the sad affections to fear, stressing that the established powers seek to "administrate our little intimate terrors" (p.75). This launches us to a "long universal weeping" (p.75) that can be easily found in statements like "There is no reason to keep fighting"; "You're alone"; "We are smaller". Fear, defined as a sad affection, not only separates the subject from its own potentials, but is also the instrument setting in progress all the undermining necessary to the good functioning of the productive machine. It is because of fear that we accept our precarious conditions of work. It is because of fear that failed affective relations endure. It is because of fear that we become participants of a life lacking meaning and intensity in the name of security and continuity. After all, according to such a perspective, it is better saving whatever we believe is ours than losing it.

Coming from the outside as a brute force, fear coerces and minimizes - or just blocks - a clinical and critical exercise about the forms of life we have and want. In the name of an idealized image of security, fear is triggered again as a collectively shared defense mechanism, now revised and amplified. There is the risk of accepting naively such a defense, bonding in a naturalized way with the devices of security and control available in the market. When fear is crystalized in an image displayed, assumed and recognized by the collective, what we lose are the singularities that may actualize in it. These are little or even not at all considered for the benefit of a pattern of fear that was slowly transformed in a market niche, being amply annexed to subtle or ostensive forms of security devices. The market verified that fear is favorable to financial transactions (Scheinvar, 2014).

If we intend to advance our analysis about fear dissociating it from the mass perspective, we need to inquire: what happens to the body of whom is taken by fear? Which affective components are actualized in it? Which forms of life are ingrained by its experience of fear? In order to partially answer these questions, it is necessary to rate which are the singularities transposing the fearful body and which are the worlds actualized in this complex set of affections. So, we conclude that, even recognized as 
a sad affection, contemporary fear is difficult to understand. It expresses singularities that, as analyzed by Deleuze (2017), evoke signs to be deciphered. When they touch the body, these signs can unleash sensations and require explanations to what is unnamable, at least in a first view, since such experienced affections do not fit into the repertoire of already known representations. The signs of fear ravish by means of the ignorance stressed in whoever experiences it. They give us an opportunity to question and to experiment with life. So, fear does not need to be simply eliminated, such as the resolution offered by the market with its many solutions to magically stanch the mass-disseminated image of fear. What we do highlight here is that fear can offer an opportunity to welcome the foreign signs and trigger the affective sensibility of the body that receives it. Only this opening creates the possibility of analyzing what we are able to do with this thing that came to us as a menace, and also how to do it. Such a position is very different from avoiding, prescribing or consuming devices of security.

Fear may function, so, as an operator, creating other connections with our lives and the world. In this case, the foreign forces are folded in the service of life. It is a displacement of the defensive connotation of fear, composed of closure and lack of power, in favor of the experimentation of the powers of the body.

But how can we appropriate affirmatively the same foreign forces that undermines, frighten and seize our powers? Deleuze offers us a hint, insisting throughout his work $(1998,2017)$ that we need to believe in the foreign forces as something alive and mutant, something able to challenge our existence. Concealed in the instituted fear, only resentment and consumerist retraction find a way to manifest themselves. Reconnected to the world as a mobilization of disparate forces, it is possible to open the body itself to the forces and its effectiveness, even if this effort evokes sadder, undermining and uncomfortable affections. Such a possibility demands a clinical exercise that arises from the everyday encounters in which we become subjects. We need to highlight here that the notion of encounter is not restrict to the mere interrelationship of bodies. The perspective of encounter admitted here includes anything that dislocates, tears up, disturbs and requires from the subject a decipherment of the emergent signs. There is in this case a critical clinic sheltering the affections and desires and putting them into the unending production of an open existence.

\section{Fear and Biopolitics}

Compared to our ancestors, our times are living and experimenting fears in a diverse way. Hence the initial contraposition to Jean Delumeau, who was concerned as a historian with a very specific period that is certainly not ours, although some of the lines that last from past to present are somehow held - what does not necessarily imply that we do not make, live, speak and experiment the world around us differently.

Fear now objectivizes itself, it has its own shape and volume, liberated from its referential object. It is not attached anymore to our individuality, it does not belong 
just to the intimal and the private and it does not concern just to the ones who feel it. This happens because fear became a currency in our society. Global capitalism has not just internationalized the vehicles for information transmission and exchange of commodities; it has also internationalized currency as a ghost and symbol of itself. Money is not just a symbol of some product anymore, it is not the material basis that used to define if someone, some population or some country is rich or poor. Money became the empty sign signifying exclusively itself; it is a cipher, or a set of bits in computer screens of brokers and shareholders in the stock market. But it was not just money that capitalism internationalized, empting its referentiality; the same occurred, maybe in an unsuspected and unexpected way, with fear: it also has gone from means (or even reaction towards something) to "a thing in itself" (Žižek, 2014, p.267), similar to what already happens in the system of communication between shareholders in a stock market. That is how we can watch, stunned and scared, almost in real time, terrorist attacks around the world or belligerent attacks from the global powers against other countries many times under the supports of humanitarian aid; in a closer range, we can watch the raptures of violence either from the police or a criminal faction in whatever city in the country, but also in the rural areas, or even in our own backyard. Everything can scare us: from fanatic terrorism to dengue fever or chikungunya, through violence and natural or human induced disasters. Our conscience of living in times of imminent catastrophes is perpetuated and disseminated on global and local levels (Stengers, 2015).

Fear has lost a long time ago its requirement for an object by which it would determine a feature or nature to justify and legitimate itself. We discovered, finally, that fear does not need to legitimate itself: we freight and anguish ourselves because we feel it and experience it too much or too little (Ginsburg, 2014). In some way, fear became closer to the exceeding that exasperates: either by the presence of something frightening or by the nescience of what we should fear. Therefore, it is not the presence of an object or any phenomenon - neither natural, nor economical, social, political, religious or technological - that sustains the shape, volume or loudness of the existential experience of fear. It is obvious that the same object incites fear to someone and it is not frightening at all to another.

Nevertheless, as we observed in the last section, fear has a capital role as a subjective experience, being a subjective component that developed shapes of omnipresence. But this is not a subjectivation exclusively apprehensible in terms of the private or the intimate life. On the contrary, it is a social process in which subjectivity constitutes itself in perpetual motion, although stumbling, tripping and being afraid in the way. Subjectivation itself is already a phenomenon that reclaims some sort of collectivity and, therefore, a collectivity that is political in its essence.

The present time is marked by structures, models and strategies of action named (maybe to simplify the process of designation of the current events) biopolitics. According to Foucault's (1999) formulation that originated all recent discussions on this subject matter (Cascais, 2016), biopolitics are the politics of life. It concerns about all 
the phenomena directly or indirectly related to human life: from birth to death (and even after this fatidic event, since it is necessary to decide the fate of the corpses); from its physiological necessities to its "noblest" needs, which are as vital as others, since they are features inherent to the demands of the population (Foucault, 1999); from our body to our "soul". In regard to our "soul" - term used to describe all our affective life - one of the major giants inciting or blocking our subjective powers, i.e., our capacity to act in the surrounding world, is fear. In fact, it is because of fear that we are moaning all the time about security; and it is in direct relation to our fears and almost insane desires for security that biopolitics becomes relevant. According to Žižek (2014, p. 393):

[...] the two features of today's ideologico-political constellation - the rise of biopolitical control and regulation; the excessive narcissistic fear of harassment - are in effect two sides of the same coin. On the one hand, the very development of the narcissistic personality bent on "self-realization" leads to growing self-control (jogging, a focus on safe sex and healthy food, and so on), that is, subjects treating themselves as objects of biopolitics; on the other, the overt goal of state biopolitics is individual happiness and a pleasurable life, the abolition of any traumatic shocks that could prevent self-realization happiness is "a commodity that was imported from America in the Fifties," as the actress Francesca Annis once put it.

However, if happiness was an exportable commodity since the Fifties, it is noticeable that under its veil there is not a single intensifying affect able to enhance subjectivity. Happiness exported ever since is just a vile label of a narcotic sensation towards the slightest possibility - and, therefore, not even of its actual occurrence - of any pain that may reach the subject. In this sense, what was really exported - and Hollywood was prodigious at it - were heavy doses of cultural narcotics, whose goal is to undermine our subjective powers. In the name of security, of the so desired happiness and of the complete fugue of any fearful situation, we subjugate ourselves to the biopolitical strategy of narcosis and torpor; it is when biopolitics becomes narcopolitics.

Anyhow, it is always subjectivity that is viscerally affected when faced with what may be the greatest danger, i.e., its undermining, the draining of its powers and of its inherent becoming. And just because of a simple but prodigiously vile factor: the search for constant protection from all that may afflict and freight us - exterior or interior, doesn't matter, since its frontiers are tenuous and porous, to the point of blending themselves without noticing. It is necessary to change our way of thinking about our intimate relation with our fears and our narcissistic craving for protection in order to find improved possibilities to accomplish, actualize and create our subjectivities.

\section{Final Considerations}

Must we avoid fear? Is fear just the undermining of our subjectivity? Is it just the draining out of our being? Many centuries ago, Aristotle taught us that courage is 
the fair measure between total fearlessness and utter fear: in order to be really courageous, we need to hold some fear. Fear is not opposed to courage. On the contrary, the sensation of fear may even be an interesting component, since it shapes our courage. To be courageous is to know how to recognize dangers and evaluate their effective reality, and this is possible only through the sensation of fear.

Our goal in this paper, therefore, is to show that we live in times in which the undermining dimension of fear is exaggerated. This is turning us profoundly scared of everything that surrounds us: we fear in face of the simple possibility of being fearful. Such is the objectless fear that we considered previously. Maybe there is a way to reconsider our fears, recovering something from its inherent animality. All animals experience and confront the sensation of fear. But fear does not block them; on the contrary, it becomes a modulator, amongst many other, to their actions and their awareness in face of the surrounding world - it belongs to their context, helping them to live and survive.

It should not be different for us. This, maybe, is the fascinating thing: instead of recognizing ourselves as exposed, we discover that our possibilities are wider. It does not mean that we are almost omnipotent, but that our subjectivity can actualize its almost infinite virtualities amongst other subjectivities, even if - it's true - they are not always pacific, sometimes even conflicting. But is it a negation and annulation of the other implied in all the conflicting agonic relations? It does not seem so. It just takes to consider that the condition for otherness and difference is not contradiction or opposition - me or the other - but a multiple relationship lacking a conclusive synthesis.

\section{References}

Beck, U. (2011). Sociedade de risco: rumo a uma outra modernidade. São Paulo: Editora 34.

Brossat, A. (2003). La démocratie immunitaire. Paris: La Dispute.

Candiotto, C. (2010, jan.-abr.). A governamentalidade política no pensamento de Foucault. Filosofia Unisinos, 11(1), 33-43. doi:10.4013/fsu.2010.111.03

Cascais, A. F. (2016). Da biopolítica após Foucault: sustentabilidade dos sistemas e vidas insustentáveis. In M. Nalli \& S. R. V. Mansano (Orgs.), Michel Foucault: desdobramentos (pp. 173-198). Belo Horizonte: Autêntica.

Carvalho, P. R. (2014). Tédio: o cansaço do viver. Londrina: Eduel.

Deleuze, G. \& Parnet, C. (1998). Diálogos. São Paulo: Escuta.

Deleuze, G. (2017). Dois regimes de loucos. São Paulo: Editora 34.

Delumeau, J. (1989). História do medo no ocidente: 1300-1800. São Paulo: Companhia das Letras. 
Esposito, R. (2008). Termini della politica: comunità, immunità, biopolitica. Milano: Mimesis Edizione.

Esposito, R. (2009). Immunitas. Protección y negación de la vida. Buenos Aires: Amorrortu.

Ferraz, M. C. F. (2017, maio-ago.). Afeto e comunicação: sobre as construções do medo. Galáxia, (35), 32-44. doi:10.1590/1982-2554128395

Foucault, M. (1999). Em defesa da sociedade. São Paulo: Martins Fontes.

Foucault, M. (1988). História da sexualidade, I: a vontade de saber. Rio de Janeiro: Graal.

Foucault, M. (2008). Nascimento da biopolítica. São Paulo: Martins Fontes.

Freud, A. (1975). Le moi et les mécanismes de défense. Paris: PUF.

Freud. S. (1926). Inibição, Sintoma e Angústia. In: Freud, S. Um Estudo Autobiográfico, Inibição, Sintoma e Angústia, Análise Leiga e outros trabalhos (pp. 107-201), Rio de Janeiro: Imago. Vol XX.

Freud. S. (1920). Além do Princípio de Prazer. In: Freud, S. Além do Princípio de Prazer, Psicologia de Grupo e outros trabalhos (pp. 17-90), Rio de Janeiro: Imago. Vol XVIII.

Freud. S. (1930). O Mal-Estar na Civilização. In Freud, S. O Futuro de uma Ilusão, O Mal-Estar na Civilização e outros trabalhos (pp. 81-177), Rio de Janeiro: Imago. Vol XXI.

Freud. S. (1933). Novas Conferências Introdutórias sobre Psicanálise. In Freud, S. Novas Conferências Introdutórias sobre Psicanálise e outros trabalhos (pp. 13-191), Rio de Janeiro: Imago. Vol XXII.

Freud. S. (1940) Esboço de Psicanálise. In Freud, S. Moisés e o Monoteísmo, Esboço de Psicanálise e outros trabalhos (pp. 165-237), Rio de Janeiro: Imago. Vol XXIII.

Gay, P. (1989). Freud: Uma vida para nosso tempo. São Paulo: Companhia das Letras. Glassner, B. (2003). A Cultura do medo. São Paulo: Francis.

Guattari, F. \& Rolnik, R. (1996). Microfísica: cartografias do desejo. Petrópolis: Vozes.

Ginsburg, C. (2014). Medo, Reverência, Terror: Quatro ensaios de iconografia política. São Paulo: Companhia das Letras.

Han, B.-C. (2013). La sociedad de la transparencia. Barcelona: Herder.

Laplanche, J., \& Pontalis, J.-B. (1991). Vocabulário da Psicanálise. São Paulo: Martins Fontes.

Lasch, C. (1984). O mínimo eu: sobrevivência psíquica em tempos difíceis. São Paulo: Brasiliense. 
Lemke, T. (2014). Os riscos da segurança: Liberalismo, biopolítica e medo. In S. Vaccaro \& N. Avelino (Eds.), Governamentalidade e segurança (pp. 105-127). São Paulo: Intermeios.

Scheinvar, E. (2014). A indústria da insegurança e a venda da segurança. Psicol. estud., 19(3), 481-490. doi:10.1590/1413-73725000811

Stengers, I. (2015). No tempo das catástrofes. São Paulo: Cosac Naify.

Žižek, S. (2014). A visão em paralaxe. São Paulo: Boitempo.

Young-Bruehl, E. (1992). Anna Freud: uma biografia. São Paulo: Imago.

Submission: 17.5.2017

Acceptance: 1.11.2017 